\title{
Islamic Concepts of Building and Architecture
}

\section{Khaled Azab*}

There are two concepts to building and architecture in Islamic jurisprudence:

- The first prerequisite is one of strength. This attribute is one of the aspects of Islam since excellence is sought in every action taken by the Muslim, and strength is the sinews of excellence. As far as social life and business relations among people are concerned, perfection is required in every action, and if a Muslim undertakes some work for the account of another person, he should ensure that this work is well done. Such perfection can only be attained by those who have gained experience and become well versed in their trade. The Prophet (PBUH) has emphasized this by saying: "May Allah bestow His mercy on those who conscientiously carry out their work" (1), and also: "Allah is pleased when whoever of you undertakes some work carries it out in all conscience"(2). The Prophet emphasized the importance of soundness and strength in building, as was witnessed by the account narrated by Talq Ibn Ali Attameemi when he said: "I came to the Prophet (PBUH) as

* Director of The Information Department (Bibliotheca Alexandrina). 
he was building his mosque with the help of some Muslims. I was familiar with the task of treating and mixing clay, so I took the brush and started to mix the clay while the Prophet watched, then he said: 'This Hanafite is skilled at clay", and in another version : "Leave the clay to the Hanafite, he is the most skilled of you at it". This only shows that strength and soundness are a prerequisite in building not only out of the duty of perfection, but also to guarantee safety, protection and prevention of harm.

- The second prerequisite is one of aesthetics. It is the Muslims' duty to attend to their appearance and their attire because Islam is a religion of beauty and purity. The Muslim worships one God, Allah, Who is Beautiful and loves beauty. Indeed, beauty is desired in building and architecture in the same way it is sought in dressing and other aspects of life. The beauty of a building shows in its harmony and pattern, as defined by time and space and as long as this building is sound in its essence and its purpose ${ }^{(3)}$.

The Islamic art of building and architecture was governed by the two following frameworks in terms of thought:

- The first framework is the Islamic legal policy (or Sharia-based policy), which is the policy followed by the ruler or governor with regard to architecture, whether it pertains to matters of general policy or directly to building, both of which influence building and architecture.

- The second framework relates to architecture-related jurisprudence. This refers to the set of rules that flowed from the dynamic of building as a result of the interaction of individuals and their desire to build and edify, and to the ensuing questions addressed by Muslim scholars, while inferring legal rulings in accordance with the rules of jurisprudence.

The queries of Muslims to scholars came as a natural consequence of their desire to build edifices compatible with their values and their civilization. As time went by, the rulings issued by scholars in this regard accumulated to form a legal framework governing the dynamic of building in society and to which adhered both the rulers and the ruled. 
The vision of Sharia-based policy for building or architecture constitutes a general governing framework that addresses major issues rather than minor ones. It has a number of common denominators with the jurisprudence of architecture, as the latter is based on legal premises and civilisational values that are specific to the Ummah.

The Islamic jurisprudence on building is based on general concepts that the Sharia-based policy has to respect, though policymakers often bypass these generalities, as they rely on authority and power to fulfil their wishes. Politics is based on the power of the state enforcing it, while the building-related jurisprudence is based on the society that endeavours to preserve and implement the rules of this jurisprudence as perceived by scholars.

Sharia-based policy has been the subject of innumerable writings, of which the most important is the Muqaddimah of Ibn Khaldun, considered to date the most mature piece of writing in this field and which contains an important chapter on the subject. There are also countless political reference books that tackle the relationship between Sharia policy and architecture, particularly with regard to the conditions and criteria of building cities ${ }^{(4)}$.

The building-related jurisprudence, on the contrary, was not as favoured in terms of writings as Islamic legal policy was. This is attributed to the fact that the building-related jurisprudence is an applied science more linked to society than to authority. Thus, the controversy it gave rise to was addressed in the books of fatwas and incidents and, compared to the science of Islamic legal policy ${ }^{(5)}$, only a few books were totally dedicated to it.

\section{First Framework:}

Governance is based on the dynamic effectiveness through which the ruler seeks to fulfil the interests of the ruled. The scholars of Sharia policy were aware of this and wrote : "The sultan has to follow a policy which is for us one of firmness and does not limit itself to what the Sharia has explicitly stipulated"(6). 
This definition was addressed in more detail by Ibn 'Uqail Al Hanbali, to whom the previous definition is attributed, through one of his debates with a Shaafiite jurisprudent who said: "There is no politics but for what concurs with the Sharia". To this, Ibn "Uqail replied: "Politics is every practice that ensures that people are closest to righteousness and farthest from immorality, even if it has not been prescribed by the Prophet peace be upon him or conveyed through divine revelation. If you mean that there is no politics but that which concurs with the Sharia in the sense that it does not contradict it, then I grant you that. But if you intend it to be confined exclusively to what the Sharia explicitly stipulates, then this is wrong and untrue to the Companions $^{(7)}$.

The definition provided by Ibn Najim al-Hanafi in his book 'Al Bahr Al Raeq' (The Clear Sea) flows in the same direction: 'The apparent interpretation of their words is that politics is any action taken by the ruler for a perceived interest, even if no partial evidence exists thereof ${ }^{(8)}$.

With these definitions in mind, we can infer the content and essence of politics from the following points:

- The legitimacy of politics is based in essence on its fundamental necessity, as only this gives body to its legitimacy on the basis of individual or collective acceptance.

- The human relations that are concerned by politics are not individual relations but more of an expression of collective bonds: The bond of the community to the individual and the community to the community.

- Politics in essence cannot be dissociated from its purpose and objectives. These objectives simply become achievable through a given means $^{(9)}$.

If we attempt to apply these fundamentals in the vision of Shariabased politics, we will once again be able to confirm several fundamental elements that form the conventional imports of the concept of legal politics. One of these is that politics is based on 
interest-motivated jurisprudence where no text exists. Thus, the driving force of politics becomes interest, a dynamic motivation that seeks congruence with the content of the Sharia ${ }^{(10)}$. Thus, politics is subject to the ruler's vision of the nation's interests as regulated by legal restrictions. In this respect, we may infer the perception of Sharia scholars of the role of the ruler in the field of building and architecture.

Al Mawardi has identified general criteria for a settlement site. A site can only be considered fit for settlement if it complies with these criteria, which he enumerated in the course of his addressing the significance of 'misr', i.e. the city. He then identified five objectives that must be sought in the establishments of cities, namely:

- First: The pursuit of peace and serenity.

- Second: The safekeeping of assets and funds from perdition and loss.

- Third: The protection of wives and other female members from offense and humiliation

- Fourth: The fulfilment of needs in terms of goods and trade.

- $\quad$ Fifth: The earning of livelihood ${ }^{(11)}$.

If we take a close look at these conditions, we will find that they are suitable for all eras. No settlement-worthy site can be found that is lacking in the exclusive and all-inclusive conditions, as they include quietude, safekeeping of property, preservation of honor and sanctity, securing of basic needs and trade, and finally the earning of livelihood. Thus, Al Mawardi covered the social and economic and security aspects of life and firmly asserted that a place devoid of any of these conditions is not fit for human habitation ${ }^{(12)}$.

We can also cite his saying : "If one of these conditions were to remain unmet, the site would not be considered fit for settlement, and would bring about regression and destruction"(13).

Scholars of politics have defined in great detail the criteria that the statesman should take into consideration when selecting a site and 
founding cities and towns. Some of these conditions, as mentioned by Ibn Khaldun, are:

1- The town or city should be surrounded by a wall to ward off harm and damage.

2- It should be located in a naturally protected site such as a place on a hilltop, near a river or along a bay, etc.

3- The site chosen should provide plentiful clean and fresh air as prevention against diseases.

4- Water should be within easy access such as from a river or water springs.

5- Grazing lands should be available for cattle.

6- Farming lands must be available to provide food and sustenance ${ }^{(14)}$.

These conditions enable every city to grow and prosper. Ibn $\mathrm{Al}$ Azraq analysed in detail what had been written by Ibn Khaldun on the subject. He pointed out two essential objectives which should be pursued in all matters related to cities, namely the avoidance of harm and the quest for interest. In this regard, harm falls under two categories: a physical one related to the land, and this harm can be prevented by surrounding the city with a wall or building it in a naturally protected location that would be hard to reach by the enemy. The second one is related to the atmosphere and can be prevented by choosing sites blessed with clean air. It has been often noted that air that goes stale as a result of stagnation or its presence within the vicinity of contaminated waters, decomposing matter or decaying swamps spreads diseases among the animals living there.

A case in point is the city of Fez, which was highly populated when the movement of building extended in Africa. The dense population helped produce a movement of air and reduced its harmful effects, thus removing sickness and decay. But when the numbers of its inhabitants dwindled, the air became stagnant and grew foul as a result of the contamination of its waters resulting in the spread of diseases and ailments. He also cited the counter-example of a city created with no regard for the quality of its air and where many diseases broke out because of the restricted number of inhabitants. But 
when the latter became numerous, the situation changed. This was the case in the Sultan's seat in Fez when the New Fez was created, and in many other parts of the world ${ }^{(15)}$.

The second fundamental condition is the securing of interest. This is achieved through compliance with a number of criteria, including the availability of water such as when the city is located on a river or close to freshwater springs. The presence of water within easy reach of the city makes it easier for dwellers to meet their water needs. Another criterion is the availability and closeness of pastures for cattle and livestock, as people need animals for breeding, milking and riding. The presence of pastures close to the city is certainly more advantageous than the hardship of seeking far ones. Equally important is the availability of farmlands because crops provide sustenance, wood for burning and for building. Many of the farmlands' yields, in fact, form part of basic and accessory goods. Besides, the city's closeness to the sea facilitates the importation of goods from remote countries. It is no secret that all of these criteria vary according to the specific needs and requirements of the dweller ${ }^{(16)}$.

While the criteria listed by Ibn Khaldun are related to the issue per se of cities, Ibn Abi Rabie addressed the role of the governor in planning the city and described this role in great detail. The responsibilities that a ruler must shoulder in this regard are summarised by Ibn Abi Rabie in eight points:

1. To convey drinking water to the city to facilitate easy access thereto.

2. To gauge the width of roads and streets to ensure their convenience and avoid narrowness.

3. To build a mosque in the heart of the city to make it close to all its dwellers.

4. To gauge the size and number of markets needed to ensure that the inhabitants can secure all their needs in goods.

5. To set a distance between the tribes making up the city's inhabitants to ensure that rival tribes are not too close to clash. 
6. If he wishes to live there, the ruler can set up house in its most spacious parts and establish his entourage around him.

7. To surround it with a wall for protection against enemies and treat it as one single house.

8. To bring to the city as many craftsmen as needed by the inhabitants ${ }^{(17)}$.

What becomes clear from the writings of Ibn Abi Rabie, who died in $272 \mathrm{AH} / 885 \mathrm{AD}$ is the degree of awareness associated with the rational analysis of criteria in establishing cities. In fact, in conveying water to the city and guaranteeing access to drinking water without hardship, there is an indicator of the development of urban planning to a level where the selection of the location is carried out in all freedom, thus transcending the natural determinism where the planner has to make sure the city founded is built close to rivers and in sites rich in natural resources ${ }^{(18)}$.

- Water is the sinews of life and a factor in the emergence of civilisations when available. It is also a factor in their demise when it becomes scarce. Ibn Abi Rabie sets as a condition for the ruler wishing to build a city far from conventional water sources to convey this water all the way to the city, as was actually the case in many Islamic cities. Muslims brought water to Madrid from the surrounding hills which abounded with subterranean waters and which were located 7 to $12 \mathrm{~km}$ away from the city. The water was conveyed through canals in which it ran in a gradual incline that allowed the flow of water into the city. It is no wonder Andalusians chose to name their new town 'Majreet', a combination of the Arabic word "majra" and the Latin suffix "-eet" denoting abundance. The name then meant 'the town abounding with canals' referring to the underground ducts and canals that criss-crossed the town conveying water to its inhabitants. As for Jeddah, it also suffered for long from the shortage of water. When Al Maqdisi visited it, he described it as a "bustling" city of which the inhabitants were wealthy and engaged in trade but suffered greatly from the lack of water. Towards the middle of the fifth century of the Hegira, Annassir Khasru arrived 
in Jeddah and noted the absence of trees and plants despite the city's architectural and building prosperity, a state owed to the scarcity of water. During the Circassian Mamluke era, Qansuh Al Ghuri was appointed ruler over the city and took great interest in solving the water crisis. He had water conveyed from the regions located west of the city and thus contributed largely to its prosperity. At the Citadel built by Salah Eddine El Ayyoubi in Cairo, a ninety-meter-deep well was dug in rock to bring water to the fortress. The well is made of two shafts that are vertically unconnected but have the same depth, which is the reason why some historians refer to two wells instead of one. The surface area of the horizontal section of the lower well is 2.3 square meters, while this surface in the upper well is 5 square meters. The latter surface was needed in the upper well to accommodate the bulls needed for operating the waterwheel set up at the bottom of the first shaft and which draws water from the bottom of the second shaft to its level. Another couple of bulls operate a second waterwheel set up at the top of the two wells; its function is to draw water from the level of the second waterwheel to the surface. The most amazing aspect of the design and execution of the upper well is the thinness of the carved rock wall separating the bottom of the well from the sloping passage of the bulls. Its thickness was measured and found at some places not to exceed $20 \mathrm{~cm}$.

- With regard to streets, Ibn Abi Rabie maintains that they must be planned in a convenient way for human use and for the means of transport available at the time, driven either by animals or human beings. Should a revolution change the landscape of transport such as the one witnessed in modern times and which introduced the use of horse-pulled carriages followed by cars, then streets must be compatible with the means of transport and nature of their use for each age. The historians who studied Islamic cities and criticised the narrow streets were applying the standards of modern times transport and failed to take into consideration the nature of the times when these cities were built. 
- The condition of centrality in the building of mosques is explained by the need for ease of access to a facility used by people five times a day. By being central, the mosque can be reached from all directions and at more or less equal distances. The choice of the heart of the city as a location for the great mosque is perhaps reflective of the choice position that faith holds in people's hearts. The central mosque represents the bond linking all the parts of the city. In the same way that the Kaaba is the pivotal point of the world to which Muslims turn when performing their prayers five times a day, Muslims in any city seek the central mosque at the heart of the city to perform their prayers. Perhaps, the only difference between the main mosque and other mosques where the five prayers are conducted is that the first one brings the whole city together on Friday and is usually the place where the prince or ruler delivers the Friday Sermon which often carries a political and social import.

- The condition of gauging the need in markets in sufficient numbers is indicative of many things: These markets should not exceed the needs of the citizens, which would result in a collapse of prices and loss of goods, nor should they be too few and push prices upwards. It also indicates that the size of these markets should be determined in such a way as to match the size of the population $^{(19)}$.

- The condition of maintaining a distance between the various tribes making up the population and the danger of bringing together rival tribes in the residential part of the city is a reflection of far sight in urban planning, comforted by an in-depth knowledge of ethnicity. In other words, the ruler should strive to bring about an ethno-urban homogeneity and prevent ethnic clashes which would inevitably lead to segregation and transform the city into divers ethnic groups which are inappropriately distributed. In truth, many contemporary planners have not granted this phenomenon enough importance in their urban plans. This has resulted in the population's return to internal immigration on account of ethnic and family affiliations. 
- Surrounding the city with walls was a feature of cities before the industrial revolution. These walls had a twofold function : first, preserving society within the walls as one family (Ibn Abi Rabie does say : "as one household"), and second, protection in view of the scarcity of weapons at the times and the prevalence of wars, particularly in border cities. Many Islamic cities had not been enclosed, in fact, within walls, but the disintegration of the caliphate structure into statelets and the breaking out of conflicts between them led to the building of walled cities. The Crusade invasions of Syria (Ash-Sham) and the threat they posed for Egypt led to the erection of walls around cities or their restoration. When Salah Eddine (Saladin) took over the rule of Egypt, he brought with him a project for defending Egypt and liberating Syria from the Crusaders. The project included the fortification of the internal front by building a wall around the two parts of the capital of Egypt, Cairo and Fustat, to facilitate their defence, especially as Fustat, having no walls to protect it, had been burnt by the Fatimid vizier Shaur lest it should fall in the hands of the Crusaders, for it had no protective wall at the time. From the Fatimid experience, it became apparent to Salah Eddine that it would be extremely difficult to defend Fustat and Cairo at the same time. He realised that if he were to build walls for each part of the capital, each of the two cities would need its own military force to defend it and therefore the army reserved for the protection of the capital would be divided in two and weakened. Thus, it was necessary to build the wall and extend it to include Fustat and build a fortress halfway between them to serve as a command post for the army defending the capital ${ }^{(20)}$.

The development of artillery between the fifteenth and nineteenth centuries gradually reduced the importance of city walls. These walls crumbled under the onslaught of cannons and artillery developed by the Ottomans and the Europeans. With the help of cannon fire, the Ottomans spread terror unknown back then. In their battle against the Hungarians in Mohatch, cannon fire broke the line of Hungarian troops in two halves. The Ottoman cannon balls fired on the troops defending Malta in $1565 \mathrm{AD}$ reached sixty thousand 
in number, while those with which the Ottomans showered Famagosta between 1571 and 1572 AD were estimated at $18,000^{(21)}$. Gradually, Europe began to react to the crumbling of walls before the artillery, and low but thick sand barricades begun to replace walls, as cannon balls sunk into them and fizzled out. Then, the Europeans started using posts which they called cavaliers at the highest points and fitted them with defensive artillery. This system proved to be efficient, and was therefore soon generalised to all of Europe. Napoleon used this technique by setting up a fortress on the Derrassa hills from which he attacked Cairo and Al Azhar during the first revolution of Cairo ${ }^{(22)}$. This led to a gradual drop in the importance of walls and fortresses and gave birth to new concepts of defending cities. In 1919 AD, Paris removed its walls which had become obsolete and ineffective ${ }^{(23)}$.

- Ibn Abi Rabie also instructed the ruler to bring to the city all the crafts it needs, which condition is conducive to its prosperity and guarantees that all its needs are met.

It is apparent that Sharia scholars did not contribute much to what Ibn Abu Rabie wrote, though his writings were subjected to further analysis and clarification by both Ibn Khaldun ${ }^{(24)}$ and $\mathrm{Al}$ Mawardi ${ }^{(25)}$.

\section{Legal politics scholars' perception of architectural edifices:}

One question lingers about the perception by Sharia-based politics scholars of the architectural edifices related to authority and power. This relation is seen by Ibn Khaldun as a direct correlation between the might of a state and the greatness of its architectural achievements. Ibn Khaldun emphasised the variations in terms of the beauty, solemn character and strength of buildings in accordance with the might of the states. In this respect, he says: "The status of edifices can vary to such an extent that they can hardly be noticed. If we consider what has been reported to us about the Abbasids, the Umayyads and the Ubaydiyyins and if we compare the authentic accounts thereof to what we see in these states which are lower in rank, we will find a great difference owed to the variations existing in their might and the edifices of their dynasties. All monuments are a reflection of power as stated so one 
can infer from these remnants the status of states in their power, weakness, might or smallness"(26). Ibn Radwane Al Malqi ${ }^{(27)}$ considered architectural edifices as the pride and assets of the state and the means of achieving wellbeing. He enumerated the achievements of the sultans of Muslims in terms of lofty edifices imposing architectural structures $^{(28)}$.

However, scholars perceived these edifices in a different way. Caliph Annassir indulged in building in Andalusia to such extents that he had gold and silver-plated tiles in his dome at the Zahraa palace, spending huge amounts of money and fashioning the ceiling in fascinating bright yellow and virginal white. Upon its completion, he sat there with his court and asked his entourage, the viziers and the servants present there, boasting about the dome's wonders and beauty: "Have you seen or heard of a king before me who has achieved such wonder or been capable of it? They said: "By Allah, no, O Commander of the Faithful. You are unique in every respect and no other king has ever preceded you in these marvels nor have we heard of such a tale". He was delighted at their response. As he sat there, the magistrate Mundhir Ibn Said entered with his head bowed in dejection and took a seat. The King repeated what he had said about the golden ceiling and his ability to have it fashioned. Tears filled the eyes of the judge and fell on his beard, and he said: "By Allah, Commander of the Faithful, I never thought Satan, may Allah damn him, would work havoc on you to such extents, nor that you would allow him to dominate you so much, with all the blessings that Allah bestowed on you and favoured you with over all the people, so that you end up in the same status as the infidels". Annassir was then irritated and said : "Watch your words, and how can you put me on par with the infidels?" The judge said: "Yes, did not Allah say: "And were it not that (all) men might become of one (evil) way of life, We would provide for everyone that blasphemes against Allah Most Gracious, silver roofs for their houses, and (silver) stairways on which to go up" (Azzukhruf, verse 33). The Caliph grew sullen and cried in repentance to Allah, then thanked the judge and ordered the demolition of the golden dome ${ }^{(29)}$. 
Ibn Khaldun was perspicacious when he identified the link between the architectural edifices, the state and the dynamic of building. The process of urbanisation is seen by Ibn Khaldun as made up of four stages. The first stage is when the core of the city is small and its inhabitants and buildings are few. The following phase is marked by a progression in building and a diversification that accompanies the growth of population. In the third phase, building comes to a halt and the population stabilises at a certain level. Then comes the final phase or the return to square one and to the phase of simplicity and civilisational deterioration, then, at times, Allah raises after it another generation ${ }^{(30)}$.

Speaking about the first phase, Ibn Khaldun says: 'When towns are planned for the first time their inhabitants are scare as are the building materials such as stones, lime and other wall coating materials such as tiles, marble, glass, mosaic and mother-of-pearl. Thus, building is at that stage rustic and uses primitive tools'. 'Comes the second phase', Ibn Khaldun says, 'when the pace of building picks up and the citizens grow in numbers, the building materials become more available as the activity becomes more intense and the craftsmen more numerous until the city reaches its utmost limits. This phase is marked by population growth, an abundant city planning and the emergence of sophisticated building materials such as marble and mosaics.

In the third phase: "The pace of building slackens, the population recedes and the building activities diminish. As a result, building skills are lost, work diminishes in response to the dwindling population. Subsequently, less building materials such as stones, marbles and others are brought to the city. Building relies more on the materials already existing in older edifices which are transferred from one building to another as more and more buildings, palaces and houses are abandoned". This phase marks the regression of the building activity in all its forms as a result of the dwindling population, which in turn obviates the need for more building materials which are substituted by materials salvaged from existing edifices. 
In the final stage: 'The materials are moved from one palace to another and from one house to another till most of it is lost, and people revert to the rustic way of building'. This return to the origin marks a full circle that resembles the life cycle of the human being. He starts out as a child, grows up then becomes old. This is very similar to reality because urbanism is a human phenomenon that blossoms and fades away just like humans and their life conditions ${ }^{(31)}$.

Ibn Khaldun adds that these phases are closely linked to the life span of the state itself. The first phase of a state is one of foundation. It is a phase marked by lack of sophistication, shunning of overindulgence, and of harshness and bravery. The second phase, which he labelled as the phase of "autocratic" is one marked by a transition from the life of coarse simplicity or primitive building to extravagant life or sophisticated building. In the third phase, all link to primitive life disappears and is replaced by indulgence in a life of luxury that induces cowardice, loss of manliness and bravery. This is the phase of "idleness and meekness". The final stage often coincides with the demise of the state which totally falls into oblivion as Ibn Khaldun says. This marks also the demise of the civilisation istelf ${ }^{(32)}$. Before Ibn Khaldun, Al Mawardi had said: 'The state emerges at first with rough and uncompromising dispositions to ensure the obedience of people. Then it becomes moderate and straight so that the rule achieves stability and quietude, and finally ends with the spread of the tyranny and weakness resulting from decline and lack of firmness ${ }^{(33)}$.

While the luxury that accompanies building and its adornments is often a civilisational aspect that denotes elevation, it is also an important factor in the political demise of the state. Ibn Khaldun says in this regard: "Luxury, wealth, easy and peaceable life under the rule of the state leads to meekness and inactivity and a tendency to give in to majestic inclinations in matters of building and clothing, seeking abundance and sophistication in the two as much as in the furniture and objects of luxury and other accessories. The coarseness of simplicity disappears and bravery and tribalism shrink and people indulge in the wealth that Allah bestows on them. Their offspring and 
successors grow up in this luxurious life, become too arrogant to serve themselves, and develop a contempt for anything related to patriotism, and so on so forth until this becomes part of their traits and a way of life. Their tribal instincts and their bravery diminish as the generations succeed one another, until the day comes when these instincts disappear totally, signalling the end of the state"(34).

Ibn Khaldun says: "When people indulge in luxury, they develop a taste for new occupations such as singing for example, which can only be engaged in by those who have secured all the basics, and this is the last feature of a civilisation." Ibn Khaldun refers to music as an advanced form of art and as an employment ${ }^{(35)}$. The inherent danger of luxury is human's inability to defend themselves, as they get accustomed a pampered life. They may hire people to discharge their duties for them to such extents that they have recourse to a third party to defend them in return for money. It is not a secret that the mercenaries hired to defend a country are its most dangerous enemy ${ }^{(36)}$. Machiavelli says in this regard that mercenaries are useless troops being divided, greedy and having no regard for order or respect for covenants or agreements. They fake bravery before friends but are cowards before foes. They herald the end of the state at their own hands or by paving the way for the covetous from outside ${ }^{(37)}$. To a large extent, the words of Machiavelli are true, but there are special cases in history that are exceptional such as the Mamlukes, even though towards the end of their reign they presented traits similar to those of mercenaries.

\section{The Mamluke Phenomenon:}

The Mamlukes took utmost interest in architecture and edification. Having been at first a political phenomenon, they were largely motivated by politics to build and edify. The Mamluke regime was unique and no similar phenomenon can be found in ancient civilisations even though it was based on slavery as a way of raising armies. The unique character of the Mamluke system lied in its capacity to become an institution governed by strict rules, which also enabled its members to lay their hands on the power, defend the lands of Islam and fight ferocious enemies such as the Crusaders and the Mongols in particular. 
Muslim historians became aware of the importance of the Mamluke system and its dedication to defending Islam after the collapse of the Abbassid caliphate and the fall of Baghdad in the hands of the Mongol invaders. The most famous of these historians was Ibn Khaldun, who attributed this phenomenon to the Arabs' overindulgence in opulence ${ }^{(38)}$.

The creation of the Mamluke order in Egypt dates back to the reign of Assalih Najm Eddine Ayyub, who owned many white slaves from Turkey who stood by his side in his times of crisis when he was deserted by the Kurds. He bought large numbers of these slaves and instituted a strict regime for their education until they became his personal troops after the Mansura battle where they defeated the Crusaders and the Ain Jalut battle where they repelled the Mongols ${ }^{(39)}$.

Subsequently, decision-making became their prerogative in Egypt and Syria. Al Qudsi says in this regard: "The Turks are now in charge of the Muslim common people. People do not carry weapons of any kind, and saboteurs have come to be intimated by them. Muslims have come to be reassured about the safety of their families and people accepted the word of the Turks ${ }^{(40)}$.

However, this institution became weak and ineffectual for several reasons, the most prominent of which was failure to purchase, raise and educate Mamlukes at a tender age and thus ensure their loyalty to the state. Ibn Khaldun considered this activity an industry and said in this regard: "In any given state, the newly introduced breed (referring to the Mamlukes) differ in their allegiance to the head of state according to the age at which they join the service of the ruler. In normal cases, solidarity in fighting and defence is achieved through blood ties which explain the natural solidarity with parents and relatives against strangers and unrelated people, as stated above. Thus, allegiance, companionship in slavery or alliance equate family relations, for though family bonds are natural, they are also fictitious. The factors that gave birth to solidarity for the Mamlukes were companionship, mutual defence, force of habit and co-existence with the educator and mentor in all other matters of life and death. Once the homogeneity bred by all this occurs, it is followed 
by solidarity and allegiance. This is a natural process among people and the same applies in the Mamluke-breeding industry. Between the breeder and the bred is woven a special degree of bonding that confirms homogeneity. Though the blood ties are not there, the outcome of these ties is there"(41). This was reflected in the concept of the family among the Mamlukes who ruled over Egypt for more than two centuries and a half (648-923AH/1120-1520AD). For them, the family was not the one made up of the father, mother and child. They did not even have a family life as the concept is perceived despite the fact that most members of the Mamluke community insisted on marrying and having children, and also on indulging in the pleasures of having concubines, slaves and mistresses. Instead, the Mamluke regime was built on bonds that brought the Mamlukes together in slavery, freedom, education and service. The ties that bound the young Mamluke to an older one were very much similar to those of parenthood or brotherhood, and in the life of the Mamluke only one type of family ties existed. This is best illustrated by the Mamluke terminology, as the Master ${ }^{(42)}$ stands for the father, while the Agha ${ }^{(43)}$, and the Ani ${ }^{(44)}$ is the younger brother. Some Mamluke sources indicate that the term 'brother' is a synonym of the term 'khashdah' ${ }^{\text {(45) }}$ ' Fraternity' is also synonymous with 'kashdashiyya'. It was often the case that the son did not replace his father in a post nor did he inherit his fortune ${ }^{(46)}$.

In fact, it was the Mamluke who replaced his master and even inherited his property and took over his harem ${ }^{(47)}$. Clear evidence of this was in the fact that a master did not eat with his children or harem but preferred to eat with his Mamlukes. Some Mamluke deeds of ownership even stipulated that the master was more deserving than anyone else of the proceeds of the waqfs dedicated by the mamlkue ${ }^{(48)}$. Thus, the family life of the Mamlukes was not built around the relationship of husband, wife and children, but more around the bond between the master and his slaves, and the Mamlukes with each other $^{(49)}$.

However, the deterioration of this relationship based on mutual respect and fellowship was a prelude to the disintegration and collapse 
of the Mamluke state and its subordination to the Ottomans. Al Qudsi relates a story in his history book that occurred during the rule of Ashraf Barsbey (825-841AH/1422-1437AD) and reflected the deterioration of the state of Mamlukes at the Citadel where they were raised and trained. The story is of significance and hence we chose to summarise it here. It is based on an account narrated by the scholar Sheikh Shams Eddine, who was a teacher of the sultan's Mamlukes at the Citadel, to Abu Hamed Al Qudsi after he narrated it at a gathering of some princes. Two Mamlukes fought each other and one of them caused the death of the other. When news of the death reached the sultan, he sent for the master teacher. When he arrived in his presence, the sultan asked him : "Are you the teacher of this class? The teacher answered : "Yes, and I receive pay, meat and provender". The Sultan then asked : 'How much is your pay ?". "One thousand dirhams, five pounds of meat and three pounds of provender', he answered. The sultan then said : "You spend the sultan's pay, eat the meat and use the provender, and yet you teach the Mamlukes to kill one another ?". The teacher answered : "No, your Majesty, I only teach them Islam, the Quran, prayers and good morals. They have learnt to kill each other from other than me, and I know who it is". The king said : "Who would that be ?", but the teacher said : "I cannot name him for I fear him". The sultan reassured him and granted him immunity, so he said : "The Sultan is responsible for this". When the Sultan asked for clarifications, the teacher said that the newly purchased Mamluke used to cross four stations in his education, carried out in the many floors of the citadel where he spent five years at each floor. At the first floor, he is tasked with bringing shoes to people, filling water jugs for ablutions and sweeping the floor. If he manages these tasks well, he moves to the second floor where he is allowed to go out for the Friday prayer at the mosque. If he is deserving, he moves up and is allowed to stand at the gate of the palace and carry the arrows of the Agha when he is in service. If he completes the third five-year term, he moves to the fourth, qualifies for an allowance and is free to come and go with his aghas. Thus, he spends twenty years learning morals from the Aghas and the Khashdashs and being shaped by the confined and restricted life he leads, the result being that he acquires a soft and smooth 
demeanour with people, never disturbs anyone and grows up to be like that. But now, when Your Majesty hears that so and so arrived from the lands of the Circassians (new Mamaluke), he sends a horse adorned with a gold saddle to receive him in Aleppo and grants him full pay and a subordinate to serve him. So, Your Majesty cannot attribute the sin to the person who did not commit it ${ }^{\text {(50) }}$.

Another factor of the fall of the Mamluke state and its annexation by the Ottomans was the stagnation of the Mamluke institution which was unable to keep pace with development and progress and to assimilate the transformations that were occurring in the field of arms and war techniques, namely the introduction of gunfire. Actually, the Ottomans defeated the Mamlukes in the battle of Marj Dabiq in 1516 thanks to the modernity of their weapons, while the Mamlukes loathed firearms and considered that excellence in fighting was the result of equestrian skills and personal bravery ${ }^{(51)}$

There are a number of questions about how scholars perceived the Mamlukes rule which was based on slaves imported and trained in military fashion, and how legitimate this rule was.

Scholars looked to the Mamluke regime for the protection of the community since they lacked the fighting skills and the disposition to do so. They needed the help of the Mamlukes to protect society and adopted hence a military regime to establish security in the Egyptian and Syrian towns, and to protect society against any external invasion. The scholars did not pledge allegiance to a particular regime, faction or governmental system. Every stable Muslim military regime that was capable of protecting the community from harm was deemed acceptable. According to their political theory, a military state was necessary to preserve a sound organization of society, and that when the Mamlukes fought against each other over the throne, the scholars recognised the right of the victorious to rule, and safeguarded hence society against these conflicts. This also explains their acceptance in Greater Syria and Egypt of the authority of the Ottomans who triumphed over the Mamlukes ${ }^{(52)}$, since the welfare and safety of 
society were their one and only priority. Scholars helped Al Zahir Baybars to transfer the Abbassid caliphate to Egypt in order to confer legitimacy on the Mamluke reign. Scholars represented the educated component of the Islamic society and were well versed in literature, the Sharia and Islamic rites. They worked as magistrates, imams, jurists, teachers, Quran memorizers and narrators of the noble tradition of the Prophet. Some of them were employed in the sultans' courts while others worked as muhtassibin (bookkeepers) and viziers in the Mamluke government, and thus served as a link between the authority and the society.

\section{Second Framework:}

The second framework pertains to the accumulation of building and architectural experience by Muslims and the problems this activity faced and which were submitted to the scholars who provided solutions. These solutions often gave rise to general rules which were respected by the authorities having been respected by the society, and considered a Sharia-based law. This framework explains the dynamic of building in the Islamic city and the rules and criteria according to which edifices were built. Scholars recorded the jurisprudence related to building very early in history. The Egyptian scholar Abdullah Ibn Abdulhakam (214AH/829AD) wrote Kitab Al Bunyan (The Book of Building) which was mentioned in several fiqh sources though no manuscript of the book has ever been found. However, it remains an important and early indication of the development of building-related jurisprudence in the city of Fustat where Ibn Abdulhakam lived ${ }^{(53)}$.

However, this framework was not sufficiently studied. This omission resulted in the emergence of two separate schools of thought on the study of the Islamic city. The first school pertained to the old orientalist movement which oscillated in describing this city between Islamic, Arab or oriental, and saw nothing in this city save its narrow streets, its multitude of side streets, zigzagging and confusing labyrinth of alleyways and its introverted houses ${ }^{(54)}$. 
They considered in the urban aspect of these cities an unstable, anarchic and disorganized scene where ill-aired residential blocks merge as a result of their inward looking windows. The members of this school saw in the Islamic city nothing but its negative aspects, and did not attempt to understand the society and its rules. They did not either analyse the interconnected factors that contributed to giving the city its general outlook, whether these factors were political, environmental, geographical, social or religious, and without which no city or its architecture can be understood.

As a consequence, a new and more objective school of thought emerged. It viewed the city not as a chaotic agglomeration of quarters and houses, but as a way of organising the urban environment that takes into consideration the desires and real needs of the population, in total harmony with a well-integrated social composition ${ }^{(55)}$. If some parts of the city appeared to some scholars to be anarchic, they may constitute on the opposite a pattern that differs from architectural planning and has its own aesthetic value ${ }^{(56)}$.

The question raised here is the following: Were not the Islamic cities planned by the authorities? To answer this question, it is necessary to describe the nature of this city and the method of dealing with it. The ancient cities that Muslims entered in conquest were left as they were and the only additions made were the buildings needed for the practicing of Islam such as mosques. They treated the old edifices of these cities in accordance with the Sharia rulings which divided buildings into:

- Necessary buildings: these include places of worship such as mosques for prayers to be performed and fortresses, walls and outposts that serve to protect the lands of Islam;

- Recommended buildings: such as minarets, which are favoured because they serve the purpose of calling people to pray, markets where people buy the goods they need and that spare them the hardship of seeking these goods from afar. The Sharia encouraged the building of markets so that tradesmen would settle there and people would find it easy to purchase their goods. 
- Permitted buildings: such as houses built to be exploited. The Sharia has sought to preserve religion, life, property, honour and offspring. Allah has created material means that human beings use in their quest to preserve these elements. One of these means is building houses and abodes that serve to preserve the lives, safeguard belongings and honour of people, and where families prosper and the progeny learns how to remain attached to religion and loyal to society ${ }^{(57)}$.

- Proscribed buildings: These include the building of premises for abominable acts, such as bars, brothels, gambling houses, building over graves and building on lands belonging to others. This category of edifices was removed by Muslims from the old cities they conquered.

As for new cities, we have looked at Fustat as a model and there we can perceive a general plan laid out by the authorities which stops at the borders of a quarter, a district or a neighbourhood but contains enough roads to meet the needs of Muslims in accordance with the circumstances at the time of the planning and the means of transport used then. Abu Yaala Al Furaa speaks about the planning of Basra in the following terms : "The companions of the Prophet urbanised Basra during the rule of 'Umar and turned it into living quarters for the tribes of its population. They made the width of its main street 60 cubits and the width of the other streets twenty cubits. Each alleyway's width was set at seven cubits. At the centre of every neighbourhood a wide square was reserved for tethering horses and burying the dead. The houses were built directly next to each other. This was done following decisions that were taken after agreement was reached or a clear indisputable text was found, ${ }^{\text {(58) }}$.

But a question lingers on how cities and districts expanded in an organised organic way without the intervention of the authorities, and within a law that governed and bound every member of society, and which was recognised and applied by everyone out of their own will because it was inspired from the general rules of Islamic fiqh? The 
respect of religion and of the values it carries and the entrenching of this religion in society was the impetus to this.

Thus emerges in the jurisprudence of building and town planning what is known as easement and possession with prejudice. Servitude is a material and moral ownership. The material one pertains to the site of the edifice, and the moral one flows from the general values of society. Of these rights is the right to build in height, the right of easement and the right of water following ${ }^{(59)}$. As for the possesssion with prejudice, it means that the person who is the first to build acquires a number of privileges that the neighbour who comes after has to respect and take into consideration when he builds his own dwelling. The first house architecturally defines the second because of these first-comer privileges. This rule was based on the Prophet's saying: "Do not harm and accept no harm (La darar wala dirar)",(60).

Based on the above, we can formulate a conception of how the town or district take shape through the many and successive building operations carried out in accordance with the rules of building-related jurisprudence. The streets of the city become established after a period of time and their form is determined by the category of people who use them. It becomes then impossible to build further in these streets because they become the ownership of the community of Muslims and their control goes to their users. Each inhabitant in a city crosses some streets more than others, and in doing so becomes part of the group controlling the streets that he uses. Thus, the number of persons in control of a street varies from one street to another, this being conditional upon the frequency of their use of this road according to the location and direction of the road.

When a new neighbourhood is built, the construction follows on the same pattern as the other parts of the city or neighbourhood. If a given street is extensively used by pedestrians, it will become wider and its users will, in exercise of their right of easement ${ }^{(61)}$ and right of passage $^{(62)}$, ban any building that may cause the road to narrow. Building goes on and structures are erected next to each other until the 
roads take their shape and the limits become defined following the use of people. Indeed, a road is a reflection of the wishes, capacities and values of people and results from the accumulation of decisions taken by the inhabitants. It is built on a priority of use, and thus we can produce a clear explanation of how the road networks emerged, for example, in the area between the city of Fustat and the Fattimid Citadel -Cairo-, and in Bulaq, the suburb lying to the north-west of Cairo.

In consideration of the above, we can divide roads in Islamic cities into three categories:

1- Public roads ${ }^{(63)}$ such as the Great Kasbah of Cairo which links the Futuh and Zweila gates. The expansion of this kasbah came as a natural outcome of the intensive use by large numbers of citizens of this road of which the extensions are known as the Khiyamiyya, Al Mugharbilin and Assuruj, and smaller parts such as Addarb Al Ahmar, Taht Arrubu Street, Sikkat Al Habaniyya and Saleeba in Cairo. A document has mentioned the public road linking Cairo and Bulaq ${ }^{(64)}$ as a road to which all Muslims had a right $^{(65)}$. The state supervised this type of roads, maintained them and prevented any violation thereof.

2- Half public, half private roads : are of a lesser degree than public ones. Their use by the whole Muslim community is less extensive than the first one and therefore the rights of the citizens living on that street are greater. This type of roads often leads to a public road and is the starting point of a network of more private roads.

3- Private roads of which the best example is the dead-end road. This type of road is owned by the inhabitants only, hence its private nature. It includes the road that a gate separates from the public or half public half private road, the door serving as a separation and the roads beyond this gate being the property of the inhabitants of the quarter or neighbourhood which starts at the gate. One of the most eloquent examples of this is the road of Atfat Al Hammam situated behind the Zweila gate, the Atfat $\mathrm{Al}$ Misk gate in Khiyamiyya, and the gate of Harat Burjuwan. The gate served as an indication that the authority of the state in city matters stopped and 
the authority of society started. This society exercised its prerogatives in maintaining the quarter, which was made of a labyrinth of side streets which were either open or dead-ended and which criss-crossed with each other but ultimately all led to the gate. The right of easement of the streets of the quarter is restricted to the inhabitants and no one, not even a new buyer, had the right to use them in any way other than authorised by all the parties in the quarter such as to install a water drain, an arcade or a skylight ${ }^{(66)}$.

It is clear that the authority here is collective and the power rests in the hands of the community. If this community fails to reach consensus, they have recourse to a magistrate and not to the state because the power of the state is political while the court represents the Sharia and its judgement is binding. If we look at the cases submitted to the judges or ulemas for fatwas, we can infer a number of jurisprudential rulings related to the layout and building of quarters and neighbourhoods.

Cases on the gates of quarters are some of the most important cases that reveal how authority was exercised within the quarter. A member of the neighbourhood may, after approval of all the other inhabitants, build a gate for the quarter on condition that he gains the right to extend an arcade over the gate so as to extend space in his house. This right was acquired by Hassan Agha when he lodged a request with the judge to allow him to build a gate for the street of $\mathrm{Al}$ Qazzazin and, in return, build an arcade on top of it. He was given permission since no one in the quarter objected ${ }^{(67)}$. The court of al-Bab al-'Ali recorded a similar request presented by Yusuf Ibn Mohammed, who explained in his request that the gate of the quarter where his house was located in Derb Sheikh Faraj in Bulaq had collapsed a long time before and nobody had cared for its restoration. He proposed to repair the gate at his expense and build a floor on top of the gate to enlarge his house which is adjoining the gate. He obtained the permission of his neighbours and the judge authorised him to renovate the gate and build the floor ${ }^{(68)}$. 
What if an inhabitant were to object? Ibn Rami related in his book "Al I'lan Bi Ahkam Al Bayane" the story of a man in Tunisia who owned many houses in a dead-end quarter and had one neighbour, who owned a single house in the same quarter. The first man built a gate at the opening of the quarter. The neighbour with the one house complained about this action to the judge, who ordered that the gate be demolished $^{(69)}$. The laws governing quarters stipulate that the restoration or maintenance of their facilities must be carried out on equal basis by their inhabitants, unless one of them takes charge of that against a privilege granted to him by the judge.

The relationship between the inhabitants of a quarter is one of solidarity. It does not relate to the physical maintenance and preservation of the quarter but goes beyond that to the preservation of society's structure and values. The following story is an illustration of this. A group of inhabitants of the Bab Chaariyya neighbourhood approached the Hanafite judge at the Bab Shaariyya Court, Abu Al Hassan Ibn Abu Al Yussur. Among them were Jaafar Ibn Abdullah, Ahmed Ibn Sherif Mohieddine, Sherif Abdelbasset Ibn Sherif Al Qassem, Haj Shems Eddine Ibn Abi Bakr, and Haj Mansour Ibn Saud. They all complained that in their neighbourhood, located inside Derb Zaed Ennil, have come to live a group of women of disrepute, and that the inhabitants sustain prejudice as a result. The judge ordered Abu alHassan bin Aba al-Usr, the owner of the women's house, to evict them in three days, and instructed that only people of good morals be allowed to live in the quarter. This case was registered on 14 Rabie I 1016AH/1606AD. ${ }^{(70)}$

The authority of the community remained prevalent within the quarter. But with the passage of time, the post of the neighbourhood's sheikh was created. The sheikh was a citizen chosen by the inhabitants to be in charge of the daily matters of the neighbourhood. His position was voluntary and he was often one of the prominent wealthy or scholarly figures. When the state began to impose its authority over the quarters inside cities in $19^{\text {th }}$ century, the quarter lost its social unity and its authority was taken up by the state. The sheikh of the 
neighbourhood became a government employee with a salary as it turned into the eye that the government kept on the neighbourhood ${ }^{(71)}$.

While the above was the focal point of the jurisprudence related to town planning and architecture in the Islamic civilisation, there is another aspect that has confirmed the Islamic civilisational innovation in this regard, namely Muslims perception of water as the beating heart of life and a gift from Allah.

\section{Islamic Perception of Water:}

The Islamic perception of water is based on its status as the source of all life, a gift from Allah and sustenance for knowledge. In addition, water has a purification function since it cleanses the Muslim physically and spiritually. Moreover, watering another human being or an animal is considered a form of charity -zakat- in Islam. The Muslim uses water to cleanse himself before praying, which confers on water a vital importance. No house, building or place was devoid of water in Cairo, Arrashid, Cordoba, Fes, Baghdad, Damascus, Esfahan and Bukhara. The concept of water as a means of purification merged with aesthetic and even poetical ideas that took body in the water architecture that adorned the cities of the Islamic world, particularly in Andalusia with its dreamy palaces. In these palaces we notice a strong sensorial presence, particularly in the visual impact of the arabesques of Islamic art. The harmony of light and shadow, manifest in the carvings and muqarnassat (stalactite vault designs) adorned with floral decorations and golden mosaics, was always completed with water features that flowed inside the lavish halls as an element of decoration and a mandatory architectural component of Andalusian palaces. The contemplation of water in its natural environment or between the walls of a house heightened the feeling in the Muslim's soul of the greatness of Allah the bestower of this blessing. The sound of water was a source of serenity and inspired a feeling of safety. Water transferred the living and dynamic nature into closed architectural structures and converted them into gardens of marble, tiles and plaster. Water also enhances the light element of the small architectural creation by receiving and reflecting the light that falls on it and on its surroundings like a celestial body with no clear source of light. The reflection of 
sunlight on water and its penetration into its liquid body generate the seven colours of the rainbow, like a foretaste and an ephemeral indication of heaven. Thanks to its diaphanous nature, water contributes to highlighting the beauty of decorations as its transparency does not occult the pieces of multicoloured mosaics that coat the beds of fountains and ponds. Water also takes shapes that vary according to the environment where it flows. At times, it is a sweeping torrent, at others, it rises powerfully to the sky then falls down again in a perfect cycle. In many other times, it is flat and clear and its serenity is only marred by the movement of waves provoked by winds or falling water.

The princes of Andalusia have always wanted to merge the religious concept and definition of water with its nature as an aesthetic element. In the internal decorations of the columns of their palaces, the concept of the garden was recurrent. The live nature existing outside the walls of their palaces in the form of trees, flowers, fruits, sky and water, was rivalled by another garden within the walls with trees in marble (columns), fine flowers and fruits in mosaic (floral decoration), domes on muqarnass, then water, the only element that maintained its live nature as no artist could convert it into a dead nature ${ }^{(72)}$.

All of this was linked to the Islamic predilection for gardens, perhaps because they provided a drastic change and relief from the desert environment closely associated with the Arab society.

In the Islamic world, the Eden under which run rivers is the ultimate promise of eternal happiness. The Andalusian compared heaven to the city of Zahraa which was claimed to be legendary. Interest in water as an aesthetic feature in architecture was reportedly phenomenal. At the palace of the governor of Toledo existed a domed pavilion which was designed in such a way that water was conveyed through a mechanical engineering process to the ceiling of the dome before falling down in sheets of water along the sides of the pavilion which thus becomes encircled in constant rainwater. The ruler of Toledo used to sit there without a drop of water touching him. 
The Surur Palace, known also as Al Jaafariyya, housed ponds, fountains and water canals that reflected all the pavilions, thus giving them an illusion of vast space and magnifying their beauty and splendour. All of this is confirmed by the living model of Arab palaces that has survived entirely untouched, namely Al Hambra palace in $\operatorname{Granada}^{(73)}$.

\section{Benefiting from Water Resources:}

Muslims have been used to drawing benefits from the various water sources. This was reflected in their categorisation of these sources, a categorisation that clearly shows the impact of fiqh. Because water is the beating heart of life, scholars have taken special interest in its laws and rulings.

There are three categories of water: river water, well water and spring water. Each of these types has many sub-divisions.

\section{First: Rivers:}

There are three categories of rivers:

- First category: The great rivers created by Allah such as Tigris, the Euphrates and the Nile. Everyone has the right to benefit from these rivers.

- Second category: The small rivers created by Allah and of which there are two types: one type has an abundant flow of water and can be utilised by all the community. The other type has shallower waters and in this case, and starting from the higher to the lower locations, each group can benefit from the volume of two feet of dammed water, as in the hadith.

- Third category: This group includes man-made rivulets flowing from a greater river flowing close to them. In this case, the river is a common property and cannot be assigned to one person over the others.

Abu Yaala ${ }^{(74)}$ explains that this advantage is not common to all times and all countries. It may differ in five ways according to customs and needs: 
- $\quad$ Difference in the nature of the land, fertile or unfertile.

- Difference of the crops and trees cultivated.

- Difference in seasons.

- Variation in planting and harvesting seasons.

- Difference in the status of the water, flowing or stagnant, used in irrigation $^{(75)}$.

\section{Second: Wells:}

Another extracted resource is well water. The digging of wells has three situations:

- A well dug for the use of passers-by and its water is common property. Othman, may Allah be pleased with him, made a waqf of the Roma well.

- Wells that start as private but finish as public, such as the wells dug by nomads who benefit from them while stationed on the land, but after their departure the well becomes public.

- A well dug by a person for his use, on condition that when he reaches water he allows the others to water their cattle but not to irrigate their cultures. The Prophet (PBUH) said: "He who withholds water from cattle shall be deprived of the mercy of Allah on the Day of Judgement". Needless to say, irrigation consumes a lot more water than watering animals ${ }^{(76)}$.

\section{Third: Springs:}

There are three categories of springs :

- First: Springs created by Allah and not developed by human beings. The same rule applies to these springs as to rivers.

- Second: Springs developed by human beings in which case they become the property of the person who caused them to well forth.

- Third: Springs developed by a person on his own property. In this case, the person has the priority of the use of this water for irrigating his land, but he must allow cattle farmers to use the springs to water their animals ${ }^{(77)}$.

Today, water sources have become diversified and include desalinated seawater, recycled waste water in addition to rainwater. The utilisation of these waters also varies in accordance with the needs 
felt in terms of time and space, true to the saying of Abu Yaala that usage is determined as per customs and needs.

\section{Utilising Waters:}

In pre-Islamic times, customs ruled in matters of water utilisation. Nomadic tribes in the Arab Peninsula settled in certain areas. Within the precincts of the sites where they settled, called the Harem, the tribe determined the scope of its utilisation of the subterranean and surface water resources existing close to their campsite and falling within its precincts, all the while granting due respect to the rights of other tribes in neighbouring areas. Another concept existed, al hema (sanctity), and referred to the readiness of the tribe to defend its rights. It is made of two elements:

The first element determines the physical delineation of the precincts as drawn up on the lands. The second element refers to the moral and legal rights of the tribe's entity. The violation of any one of these elements resulted in the tribe's rising to defend its sanctity.

When Islam emerged as a mission of reform and renewal, it approved all the prevailing customs and conventions, but annulled all the concepts that consecrated the individual property of water and absolute easement rights, water being primarily and ultimately the property of Allah, and should be made available to all. Water became a common property that could neither be monopolised, nor owned or sold, as the Prophet's hadith says : "People are partners in three: water, pasture and fire". This clearly shows the illegitimacy of individual ownership of these three elements. Therefore, water cannot be sold. Mohammed Ibn Ishaq reports that Abdullah Ibn Abi Bakr narrated on 'Umar that Aicha said: "The Prophet (PBUH) warned against selling water". Abu Yusuf said : Our interpretation, and Allah knows better, of this is that he warned against selling water before it is poured into containers, and these containers do not include wells and pools ${ }^{(78)}$. The hadith proscribes the selling of water, but judge Abu Yusuf sees in his jurisprudence that water can be sold when the person exerts efforts in collecting it and pouring it into containers. 
In another hadith, Jaber Ibn Abdullah says: "The Prophet (PBUH) proscribed the sale of water surplus"(79). Imam Annawawi says in his interpretation of this hadith: "The injunction against the sale of water surplus came against the withholding of this water from cattle. If a person owns a well that produces water in excess of his needs and there are in the vicinity grazing lands that have no other source of water than this, the owners of the cattle are unable to let them graze unless they can water them from that well. In this case, the owner of the well is forbidden from denying the cattle access to the water surplus which he should make accessible against no return. If he does not, the owners of the cattle will not allow them to graze, and therefore his withholding of the water is tantamount to his withholding grazing"(80). Thus, the person becomes responsible for withholding two public property components: water and grazing on which an unequivocal proscription was pronounced by the Prophet. The concept of the harem and the sanctity of the campsite, which previously denoted a form of tribalism in owning the rights to benefiting from and defending water, evolved to take on a more functional character in accordance with the precepts of Islam. Indeed, Islam deals with sanctity of the sources of water such as wells, springs and clefts according their categories. Each was granted inviolable precincts that varied according to the nature of the water and its abundance. The purpose of delineating these precincts was to guarantee fairness in the distribution of water through Ijtihad following the location and movement of water in the bowels of the earth ${ }^{(81)}$.

Muslim jurisprudents have endeavoured to generalise the benefit of water to all, as a public right guaranteed by the state ${ }^{(82)}$. They even put the state in charge of cleaning public rivers and maintaining their bridges. If a source of water is owned by a given particular, it is up to them to maintain it. Imam Abu Yusuf issued many useful fatwas in how the members of these groups should carry out their duties. He said: "Your Majesty asked about a group of individuals who wished to dig a river fed by the Tigris or the Euphrates and exploit it jointly. How should they proceed ? All of them should get together and start digging from the upper levels to the lower ones. Whenever they reach 
a land belonging to one of them, that person stops digging, and so on and so forth until they reach the lowest part. Some scholars said that the river should be dug from the highest to the lowest levels. When the work is finished, the fees of everybody who has participated in the digging should be worked out. Since the river is to be used by every person who drinks from it and waters his land, all the members of the community should bear the costs jointly, each making his contribution according to his material ability. Your Majesty can apply any of these two opinions. Then he said: If the owners of the river feared its overflowing and wished to consolidate its banks but were met with the refusal of some of them to participate, and they can perceive danger in not doing so, then tell them that they should reinforce it on the basis of personal shares. If no danger is perceived, they must not be forced to do so and every person has to reinforce the stretch of the river allocated to $\operatorname{him}^{(83)}$.

\section{Sources}

(1) Ismail Al Ajlouni : Unveiling the Hidden and Clearing the Confused, vol. 1, page 513. Arrissala Institution, Beirut, 2nd Edition, 1403AH.

(2) Idem.

(3) Dr Abdulrahame Annufaissa : Responsibility of Architects and Masons. Magazine of Contemporary Jurisprudence Research, page 148, 6th year, issue No. 22, 1415AH.

(4) Nasser 'Aref : On the Sources of Islamic Political Heritage. International Institute for Islamic Thought, Hernden, Virginia, United States of America, 1994.

(5) Cf. Khaled 'Azab : Islamic Jurisprudence of Building. Presshouse of Egyptian Universities, Cairo, 1997.

(6) Saleh AI Mohammed AI Khaled AI Rasheed : The Life and Jurisprudence Choices of Abu AI Wafae Ibn 'Uqail, Vol. 3, p. 701. Unpublished Ph.D. thesis, Faculty of Sharia and Law, University of AI Azhar, 1979.

(7) Ibn Qayyim AI Jawziyya : A'Lamu AI Mawqi'iyn 'An Rabbi Al 'Alamine', vol. 4, page 460-461. Dar AI Kutub Al Haditha, 1968.

(8) Ibn Nujaim AI Hanafi : Al Bahr Raeq wa Sharh Kanz AdAddaqaqii, vol. 5, page 11. On page 70 of the same volume, the author says : 'I have not found any definition of governance by the leading scholars. In his book AI Khutat, Al Maqrizi says that the verb 'sassa' 
when affixed to an action means to carry out this action. The person becomes the 'saiss' of people by governing them, and a person can be chosen by the people to lead and govern them (sawwasahu al qaum). This is for the linguistic definition of the word "siyyassa" (governance). Then it was described as 'the set of man-made rules that guarantee the respect of morals, the preservation of interests and of order. Governance in this case is of two kinds: an equitable governance that exacts right from the tyrannical and sinful, and in this case it falls under the Sharia rules in terms of bowing to the same set of rules. Many books have been written about Sharia rulings. The other type is the inequitable governance which is proscribed by the Sharia. Commenting on this, Ibn' Abidine says in 'Minhat Al Khaleq 'ala al Bahr Ar-Raeq' that in the chapter dedicated to fornication, the author said : "Governance is any act taken by the ruler for a perceived interest, even if no particular evidence exists thereof". Mohieddine Qassem pointed out that this definition was not mentioned in Ibn Nujaim Al Hanafi's book "Kitab Assiyassa Ash-Shariyya".

- Al Maqrizi : Al Khutat. Vol. 2, page 2.

- Ibn Nujaim Al Hanafi : Sharia Policy, manuscript of the Azhariyya Library, No.496, compilations 269 and 287.

- Mohieddine Qassem: idem., pp. 77 and 78.

(9) Idem., page 85.

(10) Idem., pp. 86-87-88.

(11) Abu AI Hassan Ali Ibn Habeeb AI Basri Ash-Shafii AI Mawardi : Tasheel Annadhar wa Taajil AI Dhafar Bi Akhlaqi Al Mulk wa Siyassat AI Mulk. Page 161. Verified by Mohie Hilal AI Sarhane, revised by Hassan Assaati. Dar Annahda AI Arabiyya, Beirut 1981.

(12) Walid Al Munnais : Al Hisba ala Al Mudun wal Imrane, pp. 4647. Annals of the Faculty of Letters. University of Kuwait. 16th Annal. Thesis 106, 1995-1996.

(13) Al Mawardi : previously cited reference.

(14) Abdulrahmane Ibn Muhammed Ibn Khaldun : Al Muqadimmah, pp. 244-245, Dar Ibn Khaldun, Alexandria, 1998.

(15) Ibn Al Azraq : Badaii As-Sulak, vol. 2, page 764.

(16) Idem., pp. 765-766.

(17) Ibn Abi Rabie : Suluk Al Malek fi Tadbir Al Mamalik, page 192. Authenticated by Naji Attakriti. Dar Al Andalus, Beirut, 1981.

(18) Waleed Al Munnais : "Religious Interpretation of Urbanisation", page 22. Theses of the Kuwaiti Geographic Society. Thesis No. 22, February 1984. 
(19) Ibid., page 22.

(20) Ussama Abdulnaim : Walls of Salah Eddine and their Role in the Survival of Cairo until the Mamluke Era, pp. 35-36-37. A Masters thesis. Faculty of Archaeology, University of Cairo, 1992.

(21) Vernon Brodel : Material Civilisation, Economy and Capitalism, Vol. 1, pp. 54-543. Translated by Dr Mostafa Maher. Dar Al Fikr Liddirassat, Cairo, 1993.

(22) Abdulrahmane Al Hanafi Al Jabarti : Wondrous Monuments in Biographies and Tales, vol. 3, pp. 34-35. Al Anwar Al Muhammadia Press, Cairo, 1043AH.

(23) Seddiq Shihab Eddine : Town Planning and History of Fortresses, page 453, Al Imara Magazine, 9th issue, 1939.

(24) Ibn Khaldun : Al Muqaddimmah, pp. 244-245.

(25) Al Mawardi : Tasheel Annadhar, pp. 161-162-163.

(26) Ibn Khaldun : Al Muqaddimah, pp. 224-242-243

(27) Abulqassem Abdullah Ibn Yusuf Ibn Radwan Annajari Al Khazarji. He was born in 718AH/1318AD in Malaga in Andalusia. He was a magistrate in Malaga then migrated from Andalusia to work in the court of the Merinids in Morocco. He died in 783AH/1381AD and left behind many books most of which were in the form of letters to the Merinid dynasty.

See the preface of Dr. Ali Sami Annashar in his authentication of the book : Ash-shuhub al-lami'a fi ass-Siyassa an-Nafi'a of bin hadwan, pp. 3-31, Dar Athqafa, Casablanca, 1984.

(28) Ibid., page 217.

(29) Dr. Akram Diaa Al 'Umari : Values of Islamic Society from a Historical Perspective, vol. 1, page 136. Series of Kitab Al Ummah (39), Qatar, 1994.

(30) Ibn Khaldun : Al Muqaddimah, page 858. Authenticated by Dr Ali Abdulwahed Wafi. Edition of Lajnat Al Bayane Al Arabi, 1958.

(31) Waleed Al Munnais, idem., page 48.

(32) Zainab Al Hadhari : Philosophy of the History of Ibn Khaldun, pp. 207-211. Dar Aththaqafa of Beirut, Cairo, 1979.

(33) Al Mawardi : Tasheel Annadhar wa Ta'jeel Ad-Dhafar, page 155.

(34) Ibn Khaldun, Al Muqaddimah, vol. 2, page 424. Authenticated by Ali Abdulwahid Wafi.

(35) Idem., vol. 3, page 969.

(36) Waleed Al Munnais, idem., page 50.

(37) Mechiavelli : The Prince, page 78. Translated by Khairi Hammad. Dar Al Afaq Al Jadida, Beirut, 1981. 
(38) Ibn Khaldun : Al Muqaddimah, page 192.

(39) Al Maqrizi : Al Khutat, vol. 2, pp. 236-237.

(40) Abdu Hamed Muhammed Abdullah Al Qudsi : Duwal Al Islam Ash-Sharifat Al Bahiyya, pp. 119-124. Authenticated by Sobhi Labeeb and Ulrich Harmon, German Institute for Oriental Studies, Beirut, 1997.

(41) Ibn Khaldun, Al Muqaddimah, pp. 129-130.

(42) Ustadh (master) is an arabicised term, as there is no word in Arabic where the letters 'sin' and 'dhal' can be found together. It is a Persian word meaning the master or the famous. During the Mamluke era, the title of ustadh was also given to the tradesman or master who purchases and raises the Mamluke.

- Dr. Hassan Al Basha : Al Funun Wal Wadaif Ala Al Athar, vol. 1, pp. 59-63.

- Dr Said 'Ashour: The Mamluke Era in Egypt and Greater Syria, p. 389. Dar Annahda Al Arabiyya, 1965.

- Dr Ahmed Abdulrazzaq : The Mamlukes and the Concept of Family, page 189. The Magazine of the Faculty of Archaeology, Cairo University, 2nd issue, 1977.

(43) Agha, a word of Mongol origin, means the elder brother and is very recurrent in the history of the Mongols. The word became part of Persian and was used by writers who lived after the invasion of Genghiz Khan. Its plural is Aghan, Aghawan, or Aghayan.

- Dr. Hassan Al Basha : Al Funun Wal Wadaiif. Vol. 1, p. 136.

- Dr Ahmed Abdulrazzaq: idem, page 189.

(44) Ani or Ayani, pl. Aniat. The origin of the word is Aniak or Apnak, a Mongol word that means the younger brother, and was very commonly used in the history of the Mongols.

- Dr Ahmed Abdulrazzaq: idem., page 189.

(45) Kashdash, or khajdash, arbicised term for the persian word khawajatash, or comrade in service, slavery or freedom.

- Dr Ahmed Abdulrazzaq : idem, page 189.

(46) Al Maqrizi : Assuluk fi Maarifati Duwali Al Muluk, vol. 3, page 390.

- Dr Ahmed Abdulrazzaq: idem, page 189.

(47) Ibid., page 189.

(48) Deed of Al Ghuri's Waqf. Archives of the Egyptian Ministry of Waqfs, Cairo, No 883.

- Dr Ahmed Abdulrazzaq: idem, page 190.

(49) Ibid., page 190. 
(50) Al Qudsi, idem, pp. 128-130.

(51) On the resistance of the Mamlukes to technological development in weaponry, cf. :

- Dr Abdulrahmane Zaki : Ibn Ayyas and the Use of Firearms, page 97. Proceedings of the Ibn Ayyas conference. Studies and Research of the Egyptian Association of Historical Studies and the National Book Institution, 1977.

- On the concept of equestrian excellence and fighting skills of the Mamlukes, cf. the dialogue that took place between Sultan Selim and the Mamluke prince Qortibey in the aftermath of his capture by the Ottomans.

- Dr Ibrahim Tarkhan : Egypt under the Circassian Mamlukes, pp. 201202, Cairo, 1969.

(52) Eire Lapidus : Islamic Cities in the Mamluke Era, pp 219-220. Translated by Dr. Ali Madhi. Al Ahliyya Institution for publishing and distribution, 1987.

(53) Fareed Suleiman : Scholars and Cities, pp. 89-90. Arab Historical Magazine for Ottoman Studies, Tunis, issue 9-10, 1994.

(54) De Planhol : The Geographical Fundations of the History of Islam, page 49, Paris, 1968.

Ballbas (T), the Muslim Cities of Spain (A.I.E.O), VI, p. 25, 19421947.

(55) Chevalier, D : The Arab City in our Historical Perspective : the Social Space of the Arab City, page 12, Paris, 1969.

(56) Dr. Farid Suleiman : idem, page 84.

(57) Ebraheem Ibn Yusuf Al Faez : Building and Its rules in Islamic Fiqh, pp. 85-158. PhD thesis, High Institute for Magistrates, University of Imam Muhammad Bin Saoud, Riyadh, 1985.

(58) Abu Yaala, Muhammed Ibn Hussein Ibn Al Furaa Al Hanbali : Royal Decrees, page 213, Dar Al Fikr, Cairo, 1974.

(59) Khaled 'Azab : Jurisprudence of Islamic Architecture, pp. 103, 104, 105, 106. Presshouse of Egyptian Universities, Cairo, 1997.

(60) The hadith "Do not harm and accept no harm" (la darar wala dirar) is one of the five main fundamental hadiths on which the Islamic fiqh is based. The other four are "Your actions are defined by your intentions", "Religion is giving advice", "Avoid what I warn you against, and do as much as you can of what I instruct you to do". Cf. Al Qurshi, Yahya Ibn Adam, "Al Kharaj, page 97, revised by Ahmed Shaker, Dar Al Maarifa, Beirut, 1979. Dr Albarno explains these general principles in the following : 1. Actions are defined by their objectives, 2. No harm 
and no acceptance of harm, 3. Doubt removes certainty, 4. Hard work brings ease, and 5. Custom rules. Mohammed Sedqi Albarno : A Brief Explanation of the General Rules of Fiqh, Arrissala Institution. Beirut, $1404 \mathrm{AH}$.

(61) The right of easement is a form of negative property in the Sharia. It is a material right confined to real estate since it benefits another property owned by other than the first owner, whoever he may be. For example, running water through the property of the neighbour, conveying waste water from a given point, or crossing through the land of a third party. Once the right of easement is established, it becomes permanent unless its continuity causes harm to the others. Many conditions can give rise to the right to utilisation, namely : 1 . common property of facilities such as roads, rivers and public drainage. Every estate near to these facilities has the right of passage, irrigation and the drainage of excess water, because these benefits are common to all people and can be enjoyed by them as long as they do not prejudice the rights of others. 2. Terms of contract : such as when the seller sets as a condition for the buyer the right of passage or access to water on another land owned by him, the condition thus establishing these rights. 3. Lapse of time: the right of easement on an old property when people cannot determine the time this right was established, but the assumption is that it was established for a legitimate reason and in the pursuit of the wellbeing of people, until the opposite is proven. See Dr. Wahbah Al Zuhayli, Islamic Fiqh and Its Evidence, vol. 5, pp. 589-590, Arrissala Institution, 1984, Suleiman Ibn Wael Altwaijri : Right of Easement : A Comparative Study, PhD thesis. Manuscript of Um Al Qura University, 1400AH, and Khaled 'Azab, idem, pp. 104-105.

(62) Right of passage : the right of a person to reach his property, whether it is a house or a land, through a road that is either public or private owned by him or by a third party or by both. Dr Wahbah Al Zuhaili : Islamic Fiqh and Its Evidence. Vol. 5, page 607.

(63) Al Maqdisi defined this type of road as the road free of individual claims and through which all people have the right to pass. Its benefits are general and extend to every person who uses it. It is prohibited to engage in any action on this road that may undermine the right of passers-by, since the use of the road/street is public and not private. $\mathrm{Al}$ Maqdisi, Abu Hamed : Valuable Express Benefits of the Use of the Roads of Cairo in the Doctrines of the Four Imams, page 22. Revised by Amal Al 'Amri, Egyptian Monuments Authority, Series of One Hundred Books, 1988. 
(64) Records of the Bab Al 'Aali Courthouse in Cairo. Record 73, section 13, page 605 .

(65) Cf. Al Assyouti on The Comprehensive Book of Fatwa chapter on "Excellence in Delineating Roads". Al Assyouti was an Egyptian jurist who lived during the Mamluke Era. It is easy to identify from his writings the categories of roads and rules related thereto and the type of control inhabitants exercised over these roads. Al Assyouti, Jalal Eddine, on The Comprehensive Book of Fatwas, pp. 198-208. Cf. also Annawawi, Abu Zakariyya Yahya Ibn Sharaf Addimashqi : The Eden of Seekers, vol. 4, pp. 204-205-206. Publications of the Islamic Office in Beirut, undated.

(66) Dr Wahbah Al Zuhaili, ibid., pp. 616-611-612.

(67) Deed of Hassan Agha's waqf.

(68) Records of the Bab Al 'Ali Court. Record 193, Section 883, page 240.

(69) Ibn Arrami, Mohammed Ibn Ibrahim Allakhmi : Al I'lam Bi Ahkam Al Bunyan, pp. 196 and 104. Magazine of Malekite Fiqh, Ministry of Justice, Kingdom of Morocco. Issues 2, 3 and 4, Zhul Qi'da, $1402 \mathrm{AH}$.

(70) Bab Al 'Aali Court, record 87, page 11, section 45.

(71) Abdulhamid Suleiman : Systems of Security Management in Ottoman Egypt, page 68. Magazine of the Faculty of Arts, University of Cairo, issue No 75, 1992.

Dr. Abdulmun'im Jemi'i, the Sheikhs of Cairo Quarters in the 19th Century, pp. 63-68, the Egyptian Historical Magazine, vol. 39, 1996.

(72) See "The Magnificence of Andalusia Palaces, namely Al Hambra Palaces", by Mohammed Al Jamal, Historical Writings on the Achievements of Yusuf I in Al Hambra Palaces. PhD thesis at the Faculty of Letters, University of Alexandria, 1993.

(73) Sherif Jah, Margarita Jovet : The Water Mystery in Andalusia, pp. 6465. Arab Institute for Co-operation, Madrid, 1999.

(74) Abu Yaala : Muhammad Ibn Al Hussein Ibn Al Furaa Al Hanbali. Cf. his biography in Tabaqat Al Hanabilat by Ibn Rajab, vol. 2, page 193.

(75) Al Furaa : Royal Decrees, page 215, anthenticated by Hamed Al Fuqqi. Dar Al Fikr, Cairo, 1974.

Dr Waleed Al Munnais : Religious Interpretation of Urbanisation, pp. 32-33, Kuwaiti Geographic Association and the Geography Department at the University of Kuwait. Joint publication, 62, February, 1984.

(76) Al Furaa, ibid. pp. 217, 220

(77) Ibid., pp. 217, 220. 
(78) Abu Yusuf Yaacoub Ibn Ibrahim : Al Kharaj, 2nd edition, Cairo, 1352 AH, page 97.

Dr Mahmud Rifai, Baghdad Abdulmumin : Rights of Water Utilisation in Islam, Addara magazine, issue No. 1, year 19, Riyadh, Shawwal, $1413 \mathrm{AH}$.

(79) Imam Muslim, the Saheeh, interpreted by Imam Annawawi. Vol. 4, page 73 .

(80) Ibid., Vol. 4, pp. 73-74.

(81) Ibid. Vol. 4, pp. 73-74.

(82) Dr Mahmud Al Rifaii, Idem, page 71.

(83) Abu Yusuf : Al Kharaj, pp. 202-203, Cairo, 1973. 